\section{JURNAL ABDIMAS

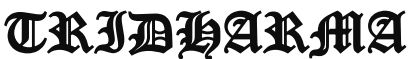

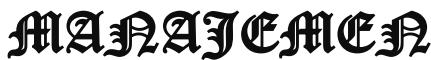

\title{
KISAH NABI SEBGAI PENINGKATAN MOTIVASI DALAM KEGIATAN SANTRIWAN/WATI DITAMAN PENDIDIKAN ALQUR'AN
}

\author{
MIFTAHUL HUDA \\ Mutmainnah, Hanum Puspa Dhiani , Ma'fiyah \\ Dosen Fakultas Ekonomi Universitas Pamulang \\ Email: dosen01720@unpam.ac.id
}

\begin{abstract}
ABSTRAK
Pengabdian ini berjudul Kajian Kisah Nabi Sebagai Peningkatan Motivasi Dalam Kegiatan Santriwan/Santriwati Taman Pendidikan Alquran Miftahul Huda.

Tujuan pengabdian ini adalah untuk mengkaji kisah para Nabi dan menyediakan bahan pustaka Buku Ilmu Pengetahuan Umum di TPA Miftahul Huda sekaligus juga meningkatkan minat budaya baca terhadap anak sejak usia dini. Secara rinci, tujuan kegiatan ini diharapkan bias memberikan kajian kisah nabi sebagai peningkatan motivasi kepada anak-anak usia dini, memberikan penyadar tahuan kepada orang tua santriwan dan santriwati tentang pentingnya membaca pada anak sejak usia dini, memberikan penyegaran kembali kepada para tenaga pengajar di TPA tersebut.

Metode pelaksanaan pengabdian ini yang kita ambil adalah metode dengan kegiatan utama menggambar yang diselingi dengan mendongeng (storytelling) sekaligus bakti sosial dengan pengurus dan santriwan/santriwati, di Taman Pendidikan Al-Qur'an (TPA) Miftahul Huda, Pamulang, Tangerang Selatan. Pelaksanaan kegiatan ini melibatkan sepenuhnya tim dosen didalam kepanitiaan kegiatannya serta melakukan fasilitasi untuk hal-hal yang berkenaan dengan pengembangan minat baca nantinya.Dalam proses kegiatan kali ini metodenya interaktif dimana narasumber akan berinteraksi aktif dengan peserta (audience), kekuatan bercerita menjadi hal kunci dalam pelaksanaan kegiatan ini mengingat nantinya anak-anak akan dibuat suasananya mengikuti alur bicara narasumber. Di akhir acara tentunya diharapkan anak-anak bisa mendapatkan pengalaman baru setelah mendapatkan kisah yang diceritakan dalam kegiatan ini.

Kesimpulan dari pengabdian ini berdasarkan pelaksanaan kegiatan yang dilaksanakan di TPA Miftahul Huda yang berlangsung pada tanggal 22 - 25 November 2018 adalah santriwan/santriwati memiliki ketertarikan untuk membaca buku. Selain itu orang tua juga antusias dalam memahami manajemen waktu untuk membimbing anak-anaknya dalam membaca buku sesuai dengan kategori usia mereka. Secara umum kegiatan PKM dapat terlaksana dengan baik dan mendapat dukungan dari pihak Ketua RT dan Ketua TPA Miftahul Huda.
\end{abstract}

Kata Kunci:Motivasi, Membaca, Mendongeng. 


\section{JURNAL ABDIMAS

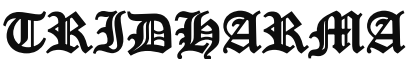

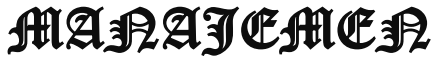

P-ISSN 0000-0000, E-ISSN 0000-0000

Jurnal ABDIMAS Vol. 1,No.1, Agustus 2019, Hal (8-21)

@Prodi Manajemen Fakultas Ekonomi Universitas Pamulang

Email: abdimasjurnal.unpam@ gmail.com Telp: (021) 741-2566

\begin{abstract}
ABSTRAC
This service is entitled Study of the Story of the Prophet as an Enhancement of Motivation in the Activities of Santriwan / Santriwati Educational Parks in the Koran Miftahul Huda.

The purpose of this service is to study the stories of the Prophets and provide literature on the General Science Book at the Miftahul Huda TPA while also increasing interest in reading culture for children from an early age. In detail, the purpose of this activity is expected to be able to provide a study of the story of the prophet as an increase in motivation for early childhood children, giving awareness to parents of santriwan and santri about the importance of reading to children from an early age, giving refreshment to the teaching staff at the TPA.

The method of implementing this service that we take is a method with the main activity of drawing which is interspersed with storytelling as well as social service with administrators and santri / santriwati in the Al-Qur'an Education Park (TPA) Miftahul Huda, Pamulang, South Tangerang. The implementation of this activity fully involved the lecturer team in the committee of activities and facilitated matters related to developing reading interest later. In this activity process the method is interactive where the resource person will interact actively with the audience, the power of storytelling is a key thing in the implementation of this activity considering that later the children will be made the atmosphere follows the speakers' flow. At the end of the event, it is expected that children can get new experiences after getting the story told in this activity.

The conclusion of this service based on the implementation of the activities carried out at the Miftahul Huda TPA which took place on 22-25 November 2018 was that santriwan / santriwati had an interest in reading books. In addition parents are also enthusiastic in understanding time management to guide their children in reading books according to their age category. In general, PKM activities can be carried out well and have the support of the Chairperson of the RT and TPA Chairperson Miftahul Huda.
\end{abstract}

\title{
Keywords: Motivation, Reading, Storytelling.
}

\section{PENDAHULUAN}

Dalam Agama Islam Nabi adalah seorang Manusia yang diberi Wahyu oleh Allah SWT. Para Nabi boleh menyampaikan wahyu yang diterima nya tetapi tidak punya kewajiban atas ummat tertentu. Nabi dan Rasul sebelum diangkat menjadi Nabi memiliki ciri-ciri kenabian atau nubuwah yang disebut juga dengan irhash. Alqur'an menyebut beberapa orang sebagai Nabi, Nabi pertama adalah Adam AS. Nabi sekaligus Rasul terakhir adalah Muhammad SAW yang ditugaskan untuk menyampaikan islam dan peraturan yang khusus kepada ummat Manusia.Disamping itu ada pepatah yang sudah sangat dikenal yaitu "buku adalah gudang ilmu" bahkan lebih ekstrim lagi ada pepatah yang berbunyi "buku adalah jendela dunia". Pepatah itu mengajarkan kepada kita semua bahwa barang siapa ingin memiliki ilmu (pengetahuan), maka kita harus memiliki buku. Bahkan bila kita ingin "melihat" dunia, 


\section{JURNAL ABDIMAS

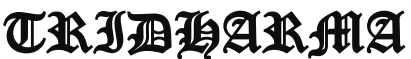

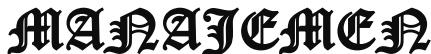

P-ISSN 0000-0000, E-ISSN 0000-0000

Jurnal ABDIMAS Vol. 1,No.1, Agustus 2019, Hal (8-21)

@Prodi Manajemen Fakultas Ekonomi Universitas Pamulang

Email: abdimasjurnal.unpam@ gmail.com Telp: (021) 741-2566 maka kita dapat mengintip dunia tersebut terlebih dahulu melalui "jendela dunia" yaitu buku.

Melalui buku kita akan memperoleh ilmu pengetahuan yang sangat banyak, karena memperoleh ilmu dari gudangnya dan menjadi orang yang "tahu segala hal" tentang dunia, karena melalui buku inilah kita dapat mengetahui dunia secara lengkap tanpa harus meninggalkan tempat kita, cukup melalui buku.

Bahkan dalam pita pada lambang Kota Tangerang Selatan yang bertuliskan slogan atau moto "CERDAS MODERN RELIGIUS" mengandung makna bahwa salah satu cita-cita dan harapan untuk mewujudkan masyarakat Kota Tangerang Selatan yang Cerdas dalam arti memiliki ilmu pengetahuan yang luas, berketerampilan baik, disertai prilaku positif. Hal ini tentunya sejalan dengan kutipan hadits shahih berikut Dari Anas bin Malik Radhiyallahu'anhu, ia berkata : "Rasulullah Shallallahu'alaihi wa sallam bersabda : "Menuntut ilmu itu adalah kewajiban bagi setiap Muslim." (HR Imam Ibnu Majah).

Pengantar di atas memberikan gambaran singkat betapa buku sangat erat kaitannya dengan ilmu (pengetahuan) yang sangat luas bahkan selain gudang ilmu, juga merupakan sarana untuk "melihat" dunia. Selanjutnya masyarakat yang cerdas dan religius salah satunya digambarkan sebagai masyarakat yang memiliki ilmu pengetahuan yang luas dan tentu saja akan diikuti sebagai masyarakat yang berketerampilan baik dan berperilaku positif. Tentu saja cerdas dan religius tersebut merupakan implikasi dari buku yang dibaca oleh masyarakat, dalam hal ini masyarakat Kota Tangerang Selatan.

Untuk memiliki masyarakat yang cerdas dan religius seperti ungkapan di atas, maka Tim PKM (Pengabdian Kepada Masyrakat) UNPAM dalam hal ini Tim Dosen UNPAM mengharapkan dapat mengkaji "kisah Nabi" dan menyediakan "gudang ilmu" serta "jendela dunia" dalam bentuk buku, sehingga masyarakat khususnya generasi muda diharapkan dapat memahami kisah para nabi dan memiliki ilmu pengetahuan yang luas. Penyediaan "gudang ilmu" dan "jendela dunia" tersebut adalah dengan memberikan akses yang lebih besar atau kemudahan terhadap masyarakat khususnya generasi muda.

Penyediaan buku ini dapat dilakukan melalui berbagai cara, di antaranya adalah: memberikan bukubuku secara gratis kepada masyarakat; menambah koleksi buku di perpustakaan sekolah, Perpustakaan, lembaga pendidikan; menambahkan koleksi buku di perpustakaan umum daerah; atau membangun wahana alternatif yang dapat memberikan akses lebih "menyenangkan" bagi masyarakat untuk membaca buku dan memperoleh informasi.

Namun pada kesempatan ini Tim PKM UNPAM menyediakan buku langsung yang dilakukan dengan cara membagikan buku secara gratis kepada santriwan dan santriwati Taman Pendidikan Al-Quran (TPA) Miftahul Huda. Selain itu, tim PKM UNPAM melakukan kegiatan kajian kisah Nabi dengan cara bercerita atau mendongeng, atau yang biasa dikenal dengan istilah storytellingkepada santriwan dan santriwati TPA Miftahul Huda dengan tujuan menumbuhkan 


\section{JURNAL ABDIMAS

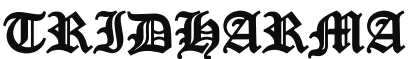

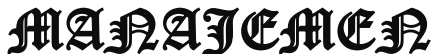

P-ISSN 0000-0000, E-ISSN 0000-0000

Jurnal ABDIMAS Vol. 1,No.1, Agustus 2019, Hal (8-21)

@Prodi Manajemen Fakultas Ekonomi Universitas Pamulang

Email: abdimasjurnal.unpam@ gmail.com Telp: (021) 741-2566 minat baca anak sejak dini dengan memahami kisah para Nabi.

\section{RUMUSAN MASALAH}

1. Memberikan pemahaman tentang pentingnya kisah Nabi bagi anak.

2. Memberikan pemahaman tentang pentingnya mencintai buku sebagai cakrawala dunia.

3. Memberikan secara cuma-cuma buku bacaan anak yang asik dan menarik.

4. Meningkatkan minat baca anak dengan menanamkan rasa cinta kepada buku.

5. Mendorong semangat membaca dalam usia dini.

\section{TUJUAN PELAKSANAAN}

Tujuan kegiatan pengabdian masyarakat ini adalah untuk mengkaji kisah para Nabi dan menyediakan bahan pustaka Buku Ilmu Pengetahuan Umum di TPA Miftahul Huda sekaligus juga meningkatkan minat budaya baca terhadap anak sejak usia dini. Secara rinci, tujuan kegiatan ini diharapkan bisa :

1. Memberikan kajian kisah nabi sebagai peningkatan motivasi kepada anak-anak usia dini

2. Memberikan penyadar tahuan kepada orang tua santriwan dan santriwati tentang pentingnya membaca pada anak sejak usia dini

3. Memberikan penyegaran kembali kepada para tenaga pengajar di TPA tersebut.

\section{TINJAUAN PUSTAKA}

\section{Pengertian Manajemen}

Pengertian manajemen secara umum dapat disimpulkan dari beberapa definisi menurut para ahli. Hal ini karena ada banyak versi definisi manajemen. Misalnya saja manajemen menurut seorang ahli bernama Mary Parker Follet yang mendefinisikan manajemen sebagai seni merampungkan pekerjaan melalui orang lain. Dari definisi tersebut didapati bahwa seseorang yang bertugas sebagai manajer dapat mengarahkan dan mengatur orang lain guna mencapai tujuan organisasi. Di sisi lain, James A.F Stoner mendefinisikan manajemen sebagai proses pengorganisasian, perencanaan, dan penggunaan SDM supaya mencapai tujuan organisasi yang sudah ditetapkan. Secara umum, pengertian manajemen merupakan suatu seni dalam ilmu dan pengorganisasian seperti menyusun perencanaan, membangun organisasi dan pengorganisasiannya, pergerakan, serta pengendalian atau pengawasan. Bisa juga diartikan bahwa manajemen merupakan suatu ilmu pengetahuan yang sistematis agar dapat memahami mengapa dan bagaimana manusia saling bekerja sama agar dapat menghasilkan sesuatu yang bermanfaat bagi orang lain maupun golongan tertentu dan masyarakat luas. Secara etimologis, pengertian manajemen merupakan seni untuk melaksanakan dan mengatur. Manajemen ini juga dilihat sebagai ilmu yang mengajarkan proses mendapatkan tujuan dalam organisasi, sebagai usaha bersama dengan beberapa orang dalam organisasi tersebut. Sehingga, ada orang yang merumuskan dan melaksanakan tindakan manajemen yang disebut dengan manajer.

\section{FUNGSI MANAJEMEN}




\section{JURNAL ABDIMAS

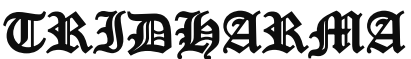

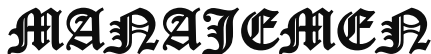

P-ISSN 0000-0000, E-ISSN 0000-0000

Jurnal ABDIMAS Vol. 1,No.1, Agustus 2019, Hal (8-21)

@Prodi Manajemen Fakultas Ekonomi Universitas Pamulang

Email: abdimasjurnal.unpam@ gmail.com Telp: (021) 741-2566
Pada dasarnya, fungsi manajemen dibagi menjadi tiga, yaitu:

1. Perencanaan (planning)

Pernecanaan adalah memikirkan apa yang akan dikerjakan dengan sumber yang dimiliki. Perencanaan dilakukan untuk menentukan tujuan perusahaan secara keseluruhan dan cara terbaik untuk memenuhi tujuan itu. Manajer mengevaluasi berbagai rencana alternatif sebelum mengambil tindakan dan kemudian melihat apakah rencana yang dipilih cocok dan dapat digunakan untuk memenuhi tujuan perusahaan. Perencanaan merupakan proses terpenting dari semua fungsi manajemen karena tanpa perencanaan, fungsi-fungsi lainnya tak dapat berjalan.

2. Pengorganisasian (organizing)

Pengorganisasian dilakukan dengan tujuan membagi suatu kegiatan besar menjadi kegiatankegiatan yang lebih kecil. Pengorganisasian mempermudah manajer dalam melakukan pengawasan dan menentukan orang yang dibutuhkan untuk melaksanakan tugas-tugas yang telah dibagi-bagi tersebut. Pengorganisasian dapat dilakukan dengan cara menentukan tugas apa yang harus dikerjakan, siapa yang harus mengerjakannya, bagaimana tugas-tugas

tersebut

dikelompokkan, siapa yang bertanggung jawab atas tugas tersebut, dan pada tingkatan mana keputusan harus diambil.

3. Pengarahan (directing)

Pengarahan adalah suatu tindakan untuk mengusahakan agar semua anggota kelompok berusaha agar dapat mencapai sasaran sesuai dengan perencanaan manajerial dan usaha.

\section{UNSUR-UNSUR MANAJEMEN}

Setiap perusahaan memiliki unsur-unsur untuk membentuk sistem manajerial yang baik. Unsur-unsur inilah yang disebut unsur manajemen. Jika salah satu diantaranya tidak sempurna atau tidak ada, maka akan berimbas dengan berkurangnya upaya untuk mencapai tujuan organisasi atau perusahaan. Unsurunsur tersebut diantaranya sebagai berikut.

\section{Human (Manusia)}

Dalam manajemen, faktor manusia adalah yang paling menentukan. Manusia yang membuat tujuan dan manusia pula yang melakukan proses untuk mencapai tujuan. Tanpa adanya manusia maka tidak ada proses kerja, sebab pada dasarnya manusia adalah makhluk kerja.

Money (Uang)

Uang merupakan salah satu unsur yang tidak dapat diabaikan.Uang merupakan alat tukar dan alat pengukur nilai. Besar-kecilnya hasil kegiatan dapat diukur dari jumlah uang yang beredar dalam perusahaan. Oleh karena itu uang merupakan alat (tools) yang penting untuk mencapai tujuan karena segala sesuatu harus diperhitungkan secara rasional. Hal ini akan berhubungan dengan berapa uang yang harus disediakan untuk membiayai gaji tenaga kerja, alat-alat yang dibutuhkan dan harus dibeli serta berapa hasil yang akan dicapai dari suatu organisasi.

Materials (Bahan)

Material terdiri dari bahan setengah jadi (raw material) dan bahan 


\section{JURNAL ABDIMAS

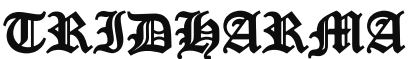

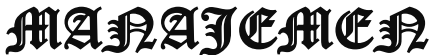

P-ISSN 0000-0000, E-ISSN 0000-0000

Jurnal ABDIMAS Vol. 1,No.1, Agustus 2019, Hal (8-21)

@Prodi Manajemen Fakultas Ekonomi Universitas Pamulang

Email: abdimasjurnal.unpam@ gmail.com Telp: (021) 741-2566 jadi. Dalam dunia usaha untuk mencapai hasil yang lebih baik, selain manusia yang ahli dalam bidangnya juga harus dapat menggunakan bahan/materi-materi sebagai salah satu sarana. Sebab materi dan manusia tidak dapat dipisahkan, tanpa materi tidak akan tercapai hasil yang dikehendaki. Machines (Mesin) Dalam kegiatan perusahaan, mesin sangat diperlukan. Penggunaan mesin akan membawa kemudahan atau menghasilkan keuntungan yang lebih besar serta menciptakan efisiensi kerja.

\section{Methods (Metode)}

Dalam pelaksanaan kerja diperlukan metode-metode kerja. Suatu tata cara kerja yang baik akan memperlancar jalannya pekerjaan. Sebuah metode dapat dinyatakan sebagai penetapan cara pelaksanaan kerja dengan memberikan berbagai pertimbangan-pertimbangan dari sasaran, fasilitas-fasilitas yang tersedia dan penggunaan waktu, serta uang dan kegiatan usaha. Perlu diingat meskipun metode baik, sedangkan orang yang melaksanakannya tidak mengerti atau tidak mempunyai pengalaman maka hasilnya tidak akan memuaskan. Dengan demikian, peranan utama dalam manajemen tetap manusia itu sendiri.

\section{Market (Pasar)}

Memasarkan produk tentu sangat penting sebab bila barang yang diproduksi tidak laku, maka proses produksi barang akan berhenti. Artinya, proses kerja tidak akan berlangsung. Oleh sebab itu, penguasaan pasar dalam arti menyebarkan hasil produksi merupakan faktor yang menentukan dalam perusahaan. Agar pasar dapat dikuasai maka kualitas dan harga barang harus sesuai dengan selera konsumen dan daya beli (kemampuan) konsumen.

Unsur- unsur manajemen menjadi hal mutlak dalam manajemen karena sebagai penentu arah perusahaan dalam melakukan kegiatan perusahaan. Selain itu, laporan keuangan juga menjadi penunjang dalam melaksanakan proses manajemen. Kini, Anda dapat membuat laporan keuangan dengan mudah menggunakan software akuntansi seperti Jurnal. Dengan menggunakan laporan keuangan dari Jurnal, Anda dapat lebih mudah melakukan kegiatan manajemen perusahaan hingga memudahkan dalam menentukan keputusan manajemen

\section{Pengertian Manajemen Sumber Daya Manusia}

Manajemen adalah ilmu dan seni yang megatur proses pemanfaatan sumber daya manusia dan sumbersumber daya lainya secara efektif dan efesien untuk mencapai suatu tujuan tertentu.

Manajemen sumber daya manusia merupakan bagian dari ilmu manajemen yang memfokuskan perhatianya pada pengaturan peranan sumber daya manusia dalam kegiatan organisasi. Hal ini dikarnakan dalam mencapai tujuanya, organisasi memerlukan sumber daya manusia sebagai pengeelola sistemnya, dan agar sistem ini berjalan, dalam pengelolaanya diperlukan beberapa aspek penting, seprti pelatihan, pengembangan, motivasi dan aspekaspek lainya. Hal ini yang menjadikan manajeman sumber daya manusia sebagai salah satu indikator penting pencapaian tujuan organisasi secara 


\section{JURNAL ABDIMAS

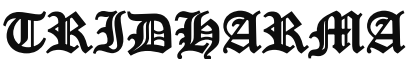

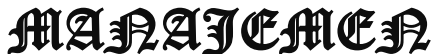

P-ISSN 0000-0000, E-ISSN 0000-0000

Jurnal ABDIMAS Vol. 1,No.1, Agustus 2019, Hal (8-21)

@Prodi Manajemen Fakultas Ekonomi Universitas Pamulang

Email: abdimasjurnal.unpam@ gmail.com Telp: (021) 741-2566 efektif dan efisien.( Mila Badriah, S.E.,M.M, 15: 2015).

Manusia selalu berperan aktif dan dominan dalam kegiatan organisasi karena manusia menjadi perencana, pelaku, dan penentu terwujudanya tujuan organisasi. Tujuan tidak mungkin terwujud tanpa peran aktif tanpa peran karyawan meskipun alatalat yang dimiliki oleh perusahaan begitu canggih. Alat-alat canggih perusahaan tidak ada manfaatnya bagi perusahaan, jika peran aktif karyawan tidak di ikut sertakan. Mengatur karyawan merupakan hal yang sulit dan kompleks karena mereka mempunyai pikiran, perasaan, status, keinginan, dan latar belakang yang heterogen yang dibawa kedalam suatu organisasi. Karyawan tidak dapat di atur dan dikuasai sepenuhnya seperti mengatur mesin, moda, dan gedung.

Manajemen sumber daya
manusia merupakan bagian dari
manajemen. Oleh karna itu, teori-teori
manajemen umum manjadi dasar
pembahasaannya mengenai pengaturan
peranaan manusia dalam menentukan
tujuan yang optimal.

Pengaturan itu meliputi masalah perencanaan (human resources planning), pengorganisasian,pengarahaan,kompen asasi,pengintregrasian,pemeliharaan, kedisiplinan dan pemberhentian tenaga kerja untuk membantu terwujudnya tujuan perusahaan, karyawan, dan masyarakat. Pengertian manajeman sumber daya manusia menurut malayu S.P. Hasibuan ( 2005: 10 ) yang menyatakan bahwa : "manajeman sumber daya manusia adalah ilmu dan seni yang mengatur hubungan dan peranan tenaga kerja yang efektif dan efisien membantu terwujudnya tujuan perusahaan, karyawan, dan masyarakat".

\section{Motivasi}

Peran manusia yang tersedia di dalam perusahaan merupakan faktor utama untuk mencapai suatu tujuan perusahaan. Untuk menghendaki manusia agar sesuai dengan yang dikehendaki organisasi, maka harus dipahami motivasi manusia yang bekerja dalam organisasi tersebut, karena motivasi inilah yang menentukan perilaku orang-orang untuk bekerja.

\section{Menurut}

Mangkunegara (2011:93) Motivasi adalah kondisi yang menggerakan pegawai agar mampu mencapai tujuan dan motifnya, sedangkan menurut Hadari Nawawi (2008: 351) motivasi adalah suatu kondisi yang mendorong atau menjadi sebab seseorang menjadi melakukan suatu perbuatan/kegiatan yang berlangsung secara sadar.

Menurut Hasibuan (2011: 143) mengatakan bahwa motivasi adalah pemberian daya penggerak yang menciptakan kegairaan kerja seseorang, agar mereka mau bekerja sama, bekerja efektif dan terintegrasi dengan segala daya upaya untuk mencapai kepuasan.

Robbin dalam Edy Sutrisno (2009: 117) menyatakan motivasi ialah "suatu kerelaan berusahaseoptimal mungkin dalam pencapaian tujuan organisasi yang dipengaruhi oleh kemampuan usaha memuaskan beberapakebutuhan individu". Sedangkan menurut M.Manulang dalam (2008: 194) yaitu motivasi merupakan pekerjaan yang dilakukan oleh seorang manajer memberikan inspirasi, semangat dan dorongan kepada orang lain, dalam hal ini karyawan untuk mengambil tindakan- 


\section{JURNAL ABDIMAS

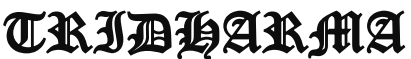

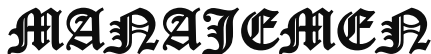

P-ISSN 0000-0000, E-ISSN 0000-0000

Jurnal ABDIMAS Vol. 1,No.1, Agustus 2019, Hal (8-21)

@Prodi Manajemen Fakultas Ekonomi Universitas Pamulang

Email: abdimasjurnal.unpam@ gmail.com Telp: (021) 741-2566 tindakan. Pemberian dorongan ini bertujuan untuk menggiatkan orangorang karyawan agar mereka bersemangat dan dapat mencapai hasil sebagaimana dikehendaki dari orangorang tersebut.

Berdasarkan uraian tersebut, diperoleh kesimpulan bahwa motivasi merupakan unsur penggerak yang mendasari seseorang dalam melaksanakan pekerjaan. Produktivitas kerja karyawan didasari oleh bagaimana motivasi yang dimiliki karyawan tersebut untuk bekerja. Jika karyawan termotivasi untuk bekerja dengan baik, maka produktivitas kerja karyawan juga akan menjadi baik dan cenderung untuk meningkat.

\section{Membaca}

Membaca adalah suatu proses yang dilakukan serta dipergunakan oleh pembaca untuk memperoleh pesan, yang hendak disampaikan oleh penulis melalui media kata-kata/bahasa tulis. Suatu proses yang menuntut agar kelompok kata yang merupakan suatu kesatuan akan terlihat dalam suatu pandangan sekilas, dan agar makna kata-kata secara individual akan dapat diketahui. Kalau hal ini tidak terpenuhi, maka pesan yang tersurat dan yang tersirat tidak akan tertangkap atau dipahami, dan proses membaca itu tidak terlaksana dengan baik (Hodgson dalam Tarigan, 2008: 7).

Membaca merupakan seluruh aktivitas yang dilakukan pembaca untuk memperoleh informasi yang terkandung dalam sebuah bahan bacaan. Produk membaca merupakan hasil dari proses membaca yakni pemahaman atas isi bacaan (Yunus, 2012: 148).

Membaca adalah suatu proses yang dilakukan serta digunakan oleh pembaca untuk memperoleh pesan yang disampaikan penulis melalui media bahasa tulis (Tarigan, 1984:7). Pengertian lain dari membaca adalah suatu proses kegiatan mencocokkan huruf atau melafalkan lambanglambang bahasa tulis.

Membaca adalah suatu kegiatan atau cara dalam mengupayakan pembinaan daya nalar (Tampubolon, 1987:6). Dengan membaca, seseorang secara tidak langsung sudah mengumpulkan kata demi kata dalam mengaitkan maksud dan arah bacaannya yang pada akhirnya pembaca dapat menyimpulkan suatu hal dengan nalar yang dimilikinya.

Membaca adalah suatu kegiatan mengamati bahasa tulis yang bertujuan untuk memperoleh suatu pengetahuan atau pesan yang disampaikan oleh penulis.

\section{Tujuan Membaca}

Tujuan utama dalam membaca adalah untuk mencari serta memperoleh informasi, mencakup isi, dan memahami makna bacaan (Tarigan, 2008: 9).

Berkesimpulan bahwa jika ingin mengetahui apa isi dari suatu bacaan maka terlebih dahulu harus membaca dan memahami apa yang ada dalam tulisan tersebut.

Menurut Farida Rahim (2008: 11) ada beberapa tujuan membaca yang mencakup :

1. Kesenangan,

2. Menyempurnakan membaca nyaring,

3. Menggunakan strategi tertentu,

4. Memperbaharui pengetahuannya tentang suatu topik,

5. Mengaitkan informasi baru dengan informasi yang telah diketahuinya, 


\section{JURNAL ABDIMAS

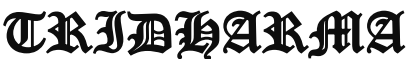

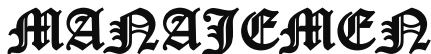

P-ISSN 0000-0000 , E-ISSN 0000-0000

Jurnal ABDIMAS Vol. 1,No.1, Agustus 2019, Hal (8-21)

@Prodi Manajemen Fakultas Ekonomi Universitas Pamulang

Email: abdimasjurnal.unpam@ gmail.com Telp: (021) 741-2566
6. Memperoleh informasi untuk laporan lisan dan tertulis,

7. Mengkonfirmasikan atau menolak prediksi,

8. Menampilkan suatu eksperimen atau mengaplikasikan informasi yang diperoleh dari suatu teks dalam beberapa cara lain,

9. Mempelajari tentang struktur teks, dan

10. Menjawab pertanyaan-pertanyaan yang spesifik

\section{Hakikat Membaca}

Kridalaksana

(1982:105)

mengemukakan bahwa dalam kegiatan membaca melibatkan dua hal, yaitu (1) pembaca yang berimplikasi adanya pemahaman dan (2) teks yang berimplikasi adanya penulis.

Syafi'ie

(1994:6-7)

menyebutkan hakikat membaca adalah:

1. Pengembangan keterampilan, mulai dari keterampilan memahami katakata, kalimat-kalimat, paragrafparagraf dalam bacaan sampai dengan memahami secara kritis dan evaluatif keseluruhan isi bacaan.

2. Kegiatan visual, berupa serangkaian gerakan mata dalam mengikuti baris-baris tulisan, pemusatan penglihatan pada kata dan kelompok kata, melihat ulang kata dan kelompok kata untuk memperoleh pemahaman terhadap bacaan.

3. Kegiatan mengamati dan memahami kata-kata yang tertulis dan memberikan makna terhadap kata-kata tersebut berdasarkan pengetahuan dan pengalaman yang telah dipunyai.

4. Suatu proses berpikir yang terjadi melalui proses mempersepsi dan
memahami
informasi serta memberikan makna terhadap bacaan.

5. Proses mengolah informasi oleh pembaca dengan menggunakan informasi dalam bacaan dan pengetahuan serta pengalaman yang telah dipunyai sebelumnya yang relevan dengan informasi tersebut.

6. Proses menghubungkan tulisan dengan bunyinya sesuai dengan sistem tulisan yang digunakan.

7. Kemampuan mengantisipasi makna terhadap baris-baris dalam tulisan. Kegatan membaca bukan hanya kegiatan mekanis saja, melainkan merupakan kegiatan menangkap maksud dari kelompok-kelompok kata yang membawa makna.

Dari beberapa butir hakikat membaca tersebut, dapat dikemukakan bahwa membaca pada hakikatnya adalah suatu proses yang bersifat fisik dan psikologis. Proses yang berupa fisik berupa kegiatan mengamati tulisan secara visual dan merupakan proses mekanis dalam membaca. Proses mekanis tersebut berlanjut dengan proses psikologis yang berupa kegiatan berpikir dalam mengolah informasi. Proses pskologis itu dimulai ketika indera visual mengirimkan hasil pengamatan terhadap tulisan ke pusat kesadaran melalui sistem syaraf. Melalui proses decoding gambargambar bunyi dan kombinasinya itu kemudian diidentifikasi, diuraikan, dan diberi makna. Proses decoding berlangsung dengan melibatkan Knowledge of The World dalam skemata yang berupa kategorisasi sejumlah pengetahuan dan pengalaman yang tersimpan dalam gudang ingatan.

\section{Mendongeng}




\section{JURNAL ABDIMAS

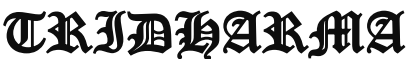

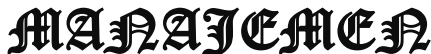

P-ISSN 0000-0000 , E-ISSN 0000-0000

Jurnal ABDIMAS Vol. 1,No.1, Agustus 2019, Hal (8-21)

@Prodi Manajemen Fakultas Ekonomi Universitas Pamulang

Email: abdimasjurnal.unpam@ gmail.com Telp: (021) 741-2566
Handajani

mengemukakan

dikemas dengan

unsur hiburan

pendidikan. Unsur

dongeng dapat ditemukan pada penggunaan kosa kata yang bersifat lucu, sifat tokoh yang jenaka, dan penggambaran pengalaman tokoh yang jenaka, sedangkan dongeng memiliki unsur pendidikan ketika dongeng tersebut mengenalkan dan mengajarkan kepada anak mengenai berbagai nilai luhur, pengalaman spiritual, petualangan intelektual, dan masalahmasalah sosial di masyarakat.

Dongeng merupakan media yang sangat efektif untuk menanamkan berbagai nilai dan etika terhadap anak. Termasuk menimbulkan rasa empati dan simpati anak. Nilai-nilai yang bisa dipetik dari dongeng adalah nilai kejujuran, kerendahhatian, kesetiakawanan, kerja keras, dan lain sebagainya. Bagi murid usia sekolah dasar (SD), ternyata mendongeng masih tetap selalu dinantikan. Cerita atau dongeng adalah salah satu media komunikasi guna menyampaikan beberapa pelajaran atau pesan moral kepada anak. Selain itu, tentu saja, metode-metode pembelajaran lainnya yang pada saat ini telah menggunakan teknologi canggih yang menarik untuk para peserta didik.

Telah terbukti bahwa
menyampaikan pembelajaran dengan cara mendongeng pun tak kalah menariknya bila dibandingkan dengan pembelajaran melalui alat peraga atau alat bantu teknologi canggih. pesan moral dapat dengan mudah disampaikan kepada anak melalui sebuah cerita atau dongeng. Tidak ada batasan usia kapan anak mulai boleh mendengarkan dongeng. Anak-anak usia prasekolah dapat mendengarkan cerita sederhana tentang hewan.

Mendongeng bisa menjadi aktivitas berkomunikasi dengan anak yang mudah dan murah. Di samping itu, mendongeng juga bisa menjadi sarana efektif dalam menyampaikan pesan pada anak. Anak tidak merasa dinasehati atau digurui oleh orang tua/pendidik karena tercipta suasana menyenangkan. Anak pun diposisikan sebagai subyek aktif yang ikut bermain peran dan/atau melibatkan seluruh inderanya untuk larut dalam cerita. Materi dongeng dapat diambil dari buku cerita anak-anak yang memuat pesan moral atau dari kejadian seharihari yang berlangsung di sekitar lingkungan tinggal anak. Kegiatan mendongeng juga akan menumbuhkan kecintaan anak pada buku karena anak menemukan banyak hal positif yang bisa diperoleh dengan membaca buku. Dongeng bisa berpengaruh pada perkembangan fisik, intelektual, dan mental anak. Ini dikarenakan keterlibatan seluruh indera anak ketika mendengarkan dongeng. Kecerdasan kognitif anak terasah lewat keterampilan berimajinasi dan menyimpulkan makna yang terkandung dalam cerita. Keterlibatan secara aktif dalam aktivitas dongeng akan memberikan pengalaman konkret pada anak sehingga akan tertanam kuat dalam struktur kognitif anak.

\section{Dongeng}

berpotensi memberikan sumbangsih besar bagi anak sebagai manusia yang memiliki jati diri yang jelas, jati diri anak ditempa melalui lingkungan yang diusahakan secara sadar dan tidak sadar. Dongeng dapat digunakan sebagai sarana mewariskan nilai-nilai luhur kepribadian, secara umum dongeng dapat membantu anak 


\section{JURNAL ABDIMAS

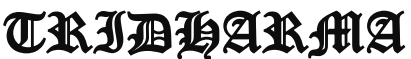

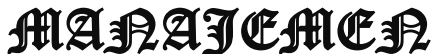

P-ISSN 0000-0000, E-ISSN 0000-0000

Jurnal ABDIMAS Vol. 1,No.1, Agustus 2019, Hal (8-21)

@Prodi Manajemen Fakultas Ekonomi Universitas Pamulang

Email: abdimasjurnal.unpam@ gmail.com Telp: (021) 741-2566 menjalani masa tumbuh kembangnya. Anak-anak dapat memahami pola drama kehidupan melalui tokoh dongeng. Melalui dongeng, anak-anak akan terlibat dalam alur cerita dongeng dalam hal ini anak-anak menumbuhkembangkan

intelektualitasnya. Dongeng mampu membawa anak melanglangbuana, memasuki dunia fantasi, menyeret mereka ke dunia antah-berantah dan membayangkan berbagai "kehidupan lain" yang tidak ada di dekat mereka, dalam hal ini dapat menumbuhkan dan menggerakkan daya ciptanya (Thobroni, 2008: 6-8).

\section{METODE PELAKSANAAN}

Dalam pelaksanaan kegiatan ini metode yang kita ambil adalah metode dengan kegiatan utama menggambar yang diselingi dengan mendongeng (storytelling) sekaligus bakti sosial dengan pengurus dan santriwan/santriwati, di Taman Pendidikan Al-Qur'an (TPA) Miftahul Huda, Pamulang, Tangerang Selatan. Pelaksanaan kegiatan ini melibatkan sepenuhnya tim dosen didalam kepanitiaan kegiatannya serta melakukan fasilitasi untuk hal-hal yang berkenaan dengan pengembangan minat baca nantinya.

Dalam proses kegiatan kali ini metodenya interaktif dimana narasumber akan berinteraksi aktif dengan peserta (audience), kekuatan bercerita menjadi hal kunci dalam pelaksanaan kegiatan ini mengingat nantinya anak-anak akan dibuat suasananya mengikuti alur bicara narasumber. Di akhir acara tentunya diharapkan anak-anak bisa mendapatkan pengalaman baru setelah mendapatkan kisah yang diceritakan dalam kegiatan ini.

\section{HASIL DAN PEMBAHASAN}

\section{Hari Pertama}

Hari pertama setelah proposal disetujui dari pihak TPA Miftahul Huda dan LPPM, tim dosen Pengabdian Kepada Masyarakat Universitas Pamulang melakukan pertemuan dan diskusi dengan pemilik TPA Miftahul Huda dan para wali santriwan-santriwati serta survei terkait tempat yang akan digunakan untuk kegiatan PKM yaitu mendongeng dengan sasaran santriwan/santriwatiTPA Miftahul Huda yang bertujuan meningkatkan daya imajinasi dan meningkatkan minat membaca buku. Kegiatan ini dilakukan pada hari Kamis, 22 November 2018. Kegiatan berlangsung dari pukul 09.00 -12.00 WIB.

2. Hari Kedua Kegiatan Pengabdian Kepada Masyarakat

a. Registrasi Peserta

Pelaksaan registrasi peserta dilaksanakan di pintu masuk TPA Miftahul Huda yang biasa digunakan sebagai tempat belajar anak-anak untuk belajar ilmu agama dan Al-Quran. Peserta adalah santriwan/santriwati TPA Miftahul Huda, Pamulang, Tangerang Selatan. Registrasi dimulai pada pukul 15.00 WIB.

b. Pembukaan Acara dan Pembacaan Ayat Suci Al-Quran

Pembukaan acara di buka oleh MC, dilanjutkan dengan pembacaan ayat suci Al-Quran oleh salah satu santriwati TPA Miftahul Huda berjalan lancar. Kegiatan ini dimulai pada pukul 15.30 WIB.

c. Sambutan Ketua TPA Miftahul Huda

Sambutan pertama diisi oleh Ibu 


\section{JURNAL ABDIMAS

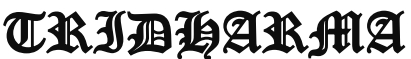

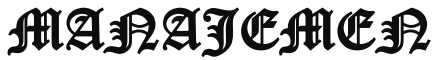

P-ISSN 0000-0000, E-ISSN 0000-0000

Jurnal ABDIMAS Vol. 1,No.1, Agustus 2019, Hal (8-21)

@Prodi Manajemen Fakultas Ekonomi Universitas Pamulang

Email: abdimasjurnal.unpam@ gmail.com Telp: (021) 741-2566
Husnaini selaku ketua TPA Miftahul Huda. Kegiatan PKM disambut sangat baik dari ketua TPA Miftahul Huda, serta Ketua TPA berharap kegiatan PKM ini dapat berkelanjutan. Kegiatan ini dimulai pukul 15.45 WIB.

\section{d. Sambutan Ketua Panitia PKM}

Sambutan kedua diisi oleh Ibu Surti Wardani, S.Sos., M.Si selaku ketua Panitia. Ketua PKM berterimakasih kepada semua pihak yang terkait sehingga acara dapat dilaksanakan dengan baik. Sambutan berlangsung hingga pukul 15.55 WIB.

\section{e. Sambutan Ketua RT 5 Pondok Salak}

Sambutan terakhir diisi oleh Bapak Ketua RT setempat, yang memberikan sambutan yang baik atas kedatangan tim PKM dosen Universitas Pamulang. Sambutan berlangsung hingga pukul .16.10 WIB, acara berlangsung dengan baik tanpa adanya faktor penghambat.

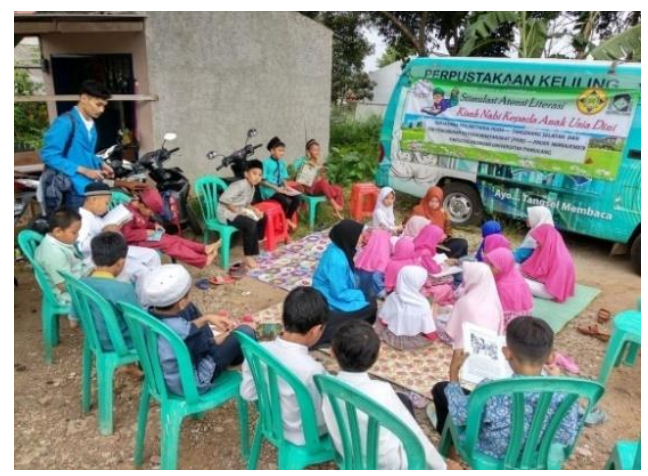

f. Kegiatan membaca buku didukung fasilitas mobil perpustakaan keliling.

Mobil perpustakaan keliling merupakan kegiatan jemput bola dengan mengunjungi langsung masyarakat. Selain itu juga sekolahsekolah dan Taman Pendidikan Alqur'an dikunjungi mobil perpustakaan keliling guna memudahkan akses baca secara gratis.
Kegiatan membaca buku ini dapat mendongkrak santriwan/wati untuk gemar membaca. Kegiatan ini dilaksanakan di samping halaman rumah TPA Miftahul Huda, kegiatan ini dimulai pada pukul 16.15 WIB. Kegiatan ini berlangsung hingga pukul 17.15 WIB.

3. Hari Ketiga Kegiatan Pengabdian Kepada Masyarakat

Hari ketiga kegiatan PKM dilanjutkan dengan kegiatan mendongeng dengan tema Kisah Nabi Isa AS, yang dimulai dengan pembacaan doa oleh salah satu santriwati, dilanjutkan dengan menyanyikan mars TPA Miftahul Huda dan senandung pembacaan Al-Fatihah. Kegiatan dilanjutkan dengan perkenalan dan ice breaking agar suasana lebih akrab dan santai dan menarik perhatian anak-anak. Kegiatan ini dimulai dari pukul 15.00 WIB sesuai jadwal kegiatan belajar santriwan-santriwati TPA Miftahul Huda. Kegiatan ini bertujuan meningkatkan daya imajinasi anak dan merangsang anak untuk meningkatkan minat baca, selain itu tujuan lainnya adalah memberikan pesan moral supaya anak-anak memiliki akhlak yang mulia. Kegiatan mendongeng berlangsung hingga pukul 17.00 WIB diakhiri dengan pembagian bingkisan.

\section{Penutup dan Pembacaan Doa}

Setelah acara mendongeng selesai dilanjutkan dengan pembacaan doa yang dipimpin oleh salah satu dosen Pengabdian Kepada Masyarakat, dilanjutkan dengan pemberian bingkisan dan buku bacaan anak-anak, sesi foto bersama, yang kemudian acara ditutup oleh MC. Kegiatan ini berlangsung hingga pukul 17.20 WIB. 

JURNAL ABDIMAS

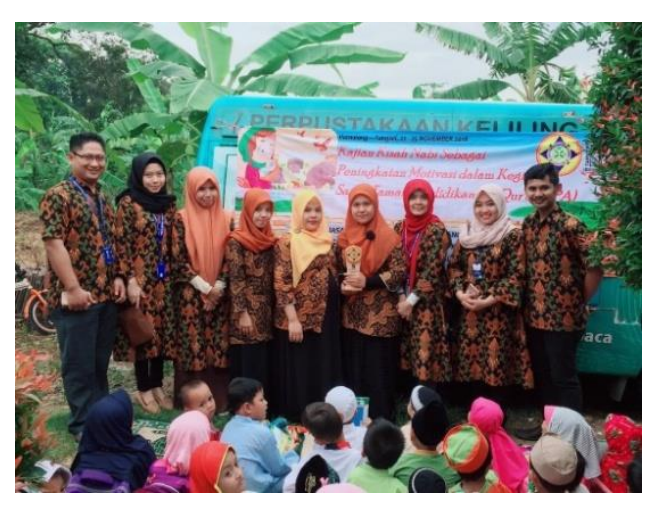

\section{KESIMPULAN DAN SARAN}

Kesimpulan

$\begin{array}{lr}\text { Berdasarkan } & \text { pelaksanaan } \\ \text { kegiatan Pengabdian } & \text { Kepada } \\ \text { Masyarakat yang dilaksanakan di TPA } \\ \text { Miftahul Huda yang berlangsung pada } \\ \text { tanggal 22 - 25 November } 2018 \text { dapat } \\ \text { disimpulkan } & \text { bahwa } \\ \text { santriwan/santriwati } & \text { memiliki }\end{array}$ ketertarikan untuk membaca buku. Selain itu orang tua juga antusias dalam memahami manajemen waktu untuk membimbing anak-anaknya dalam membaca buku sesuai dengan kategori usia mereka. Secara umum kegiatan PKM dapat terlaksana dengan baik dan mendapat dukungan dari pihak Ketua RT dan Ketua TPA Miftahul Huda.

Saran

Berdasarkan kegiatan yang sudah terlaksana beberapa saran yang dapat kami sampaikan orang tua mampu memotivasi dan membimbing anaknya untuk banyak membaca buku dibandingkan dengan bermain gadget yang lumrah ditemukan di era modern ini. Kami berharap agar semakin banyak orang tua yang peduli terhadap minat baca anak-anaknya, serta anakanak semakin gemar membaca buku.

\section{DAFTAR PUSTAKA}

A.M. Sardiman, 2001. Interaksi dan Motivasi Belajar Mengajar.
Jakarta: Raja GrafindoPersada. 224 hlmn.

Abidin, Yunus. 2012. Pembelajaran Bahasa Berbasis Pendidikan Karakter. Bandung: Refika Aditama.

Alam Handayani, Nizar dan Dody Hermana. 2008. Classroom Action Research. Rahayasa Research and training

Farida Rahim. 2008. Pengajaran Membaca di Sekolah Dasar. Jakarta : Bumi Aksara.

Handoko,T.Hani. 2012. Manajemen Personalia dan Sumber Daya Manusia. Edisi Ke-2. Yogyakarta: BPFE.

Hodgson, dalam Tarigan, 2008:7.

Skripsi Indra Rakhman, Pembelajaran Membaca Pemahaman dikelas V SD Bandung, Tidak Diterbitkan.

Kridalaksana, Harimurti. 1982. Kelas Kata dalam Bahasa Indonesia. Jakarta: Gramedia Pustaka Utama.

L.Mathis., Robert dan John H.Jackson.Manajemen Sumber Daya Manusia. PT.Salemba 4. Jakarta. Edisi 10. 2006

Malayu Hasibuan S. P. 2012. Manajemen Sumber Daya Manusia. Cetekan keenam belas. Jakarta. PT. Bumi Akasara. Mangkunegara, A.A Anwar Prabu. 2009. Manajemen Sumber Daya Manusia. Bandung: PT. Remaja Rosdakarya.

Mangkunegara.,Anwar Prabu.

Manajemen Sumber Daya Manusia Perusahaan. PT.Remaja Rosdakarya. Bandung. Cetakan ke-12. 2013

Marwansyah. Manajemen Sumber Daya Manusia. CV Alfabeta. Bandung. 2010 


\section{JURNAL ABDIMAS

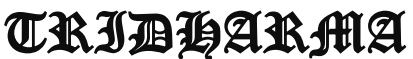

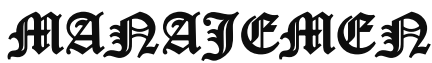

P-ISSN 0000-0000, E-ISSN 0000-0000

Jurnal ABDIMAS Vol. 1,No.1, Agustus 2019, Hal (8-21)

@ Prodi Manajemen Fakultas Ekonomi Universitas Pamulang

Email: abdimasjurnal.unpam@ gmail.com Telp: (021) 741-2566

Pasaribu, V. L. D., Susanti, F., \& Hartuti, E. T. K. (2019). MEMOTIVASI SISWA DAN SISWI SMK LETRIS INDONESIA DI DALAM MENENTUKAN PILIHAN UNTUK MELANJUTKAN PENDIDIKAN ATAU BEKERJA SETELAH LULUS

SEKOLAH. Jurnal Pengabdian Dharma Laksana, 1(2), 161-172.

Tampubolon, D.P. 1987. Kemampuan Membaca. Bandung: Angkasa.

Tim LPPM Pamulang. 2016. Buku Panduan Penelitian dan Pengabdian Kepada Masyarakat. Universitas Pamulang. Tangerang Selatan

Thobroni, M. 2016. Belajar Dan Pembelajaran. Yogyakarta: ArRuzz Media.

Sukiman dkk. 2016. Seri Pendidikan Orang Tua : Mendidik Anak di Era Digital. Kementerian Pendidikan dan Kebudayaan : Jakarta.

Syafi'ie, Imam. 1994. Terampil Berbahasa Indonesia I Petunjuk Guru Bahasa Indonesia. Jakarta : Departemen Pendidikan dan Kebudayaan 